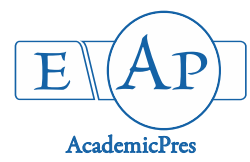

\title{
Spatial Distribution of Soil Bulk Density, Organic Carbon and pH under Different Land Use Systems along Umuahia South Local Government Area of Abia State in South Eastern Nigeria
}

\author{
Brown Mang ONWUKA*, Emmanuel Adeboye ADESEMUYI \\ Michael Okpara University of Agriculture, Department of Soil Science and Meteorology Umudike, Abia State, \\ Nigeria; onwuka.brown@mouau.edu.ng (*correspondingauthor); adesemuyi.emmanuel@mouau.edu.ng
}

\begin{abstract}
Information about spatial distribution of soil qualities in a given area is a fundamental piece of land surface prerequisites for ecological purposes, agriculture and other land use systems. The utilization of numerical methods to portray soil properties and upgrade objectivity in soil-related decision making, was applied to soil samples collected from soil under the land use systems; excavation site (EX), refuse dump site (RD), forest land (FL), continuously cultivated land (CC) and 4-year bush fallow (4-BF) along Umuahia South LGA of Abia State in south eastern Nigeria. Geostatistical technique was applied to estimate the spatial distribution and produce soil maps for each selected soil properties. Results revealed that excavation site $\left(1.70 \mathrm{Mg} \mathrm{m}^{-3}\right)$ recorded a high bulk density, while the other land use systems had a moderate bulk density. The results showed that refuse dump site had a neutral soil reaction (7.02), slightly acidic reaction was recorded under 4-year bush fallow (6.00) and forest land (5.71). Continuously cultivated land had a moderately acidic soil reaction (5.41) and organic carbon content (1.48\%). The result also revealed that forestland (2.97\%) and refuse dump site (3.20\%) had very high organic carbon content, while excavation site $(0.38 \%)$ had very low organic carbon content. This study will help land owners/users in terms of choice and adoption of land for different uses in the area.
\end{abstract}

Keywords: geostatistical technique; land use systems; spatial distribution; soil map; soil properties

\section{Introduction}

Land use system is a process constrained by human activity, affected by natural, ecological and economic conditions (Oguike and Onwuka, 2018). The effect of land use systems on soil properties is profound (Skye, 2005). These impacts are apparent over a long period of time (Braimoh and Velk, 2004). Some land use systems consist of urbanization (which comprises of housing, industry, business ventures, roads, and so forth) (Eppink et al., 2004), livestock ranching and forestry (Barlow, 2007), continuous cultivation and bush fallow system (Agoume and Birang, 2009), refuse dump site (Anikwe and Nwobodo, 2002) and excavation site (Mostafa and Nazor, 2012). Researchers have since a long time ago perceived the effects of land use systems on soil properties (Shepherd et al., 2000; Braimoh and Velk, 2004; Neris et al., 2012; Oguike and Onwuka, 2017). Forestry has caused positive changes in the soil physical properties (Shepherd et al., 2000) thereby resulting to the development of tree biomass (Versterdal et al., 2002) and increased availability of plant nutrient (Mao et al., 2010). The change of forest and pasture land into crop land is known to deteriorate soil properties, change the arrangement and stability of soil aggregates (Singh and Singh, 1996) and soils might become further liable to erosion since macro aggregates are distorted (Six et al., 2000). Continuous cropping decreases aggregate stability of soils while increasing the bulk density (Celik, 2005). Excavation has caused a decrease in the accumulation of organic matter in the soil (Croke et al., 2001), decreased soil porosity (Rab, 2003) and increased the bulk densities of soil (Rab et al., 1992).

Soil maps provide a readily available source of soil property information that can be utilized to stratify and extrapolate soil properties across an area (Bouma, 1997). Every soil map shows simplified and organized information based on the underlying soil properties and its distribution across the study area (Skye, 2005). Soil map units are arranged according to the fundamental principles of soil taxonomy (Soil Survey Staff, 1996). New computer applications enhanced widespread development, use of more detailed analytical, and predictions techniques such as geostatistics (Skye, 2005). Geostatistics can be used to analyse any features that exhibits spatial dependence (Webster and Oliver, 2001). They provide a statistically 
robust technique for analyzing the spatial arrangement of soil properties at various locations and conditions (Skye, 2005). Using geostastics, statements that are more specific can be made about the changes in spatial distributions of soil properties (Chukwu et al., 2007). Land use systems has been shown to change the variability of soil organic carbon, $\mathrm{pH}$ and bulk density (Oguike and Onwuka, 2017), while continuous cultivation was observed to increase the maximum distance of spatial dependence for soil organic matter and other properties (Cambardella et al., 1994). PazGonzalez et al. (2000) found that soils under continuously cultivated land were more homogeneous than soils under bush fallow and forestland, with reduced nugget effects of organic matter and $\mathrm{pH}$.

In Abia State, land is put to numerous utilizations driven by the expanding interest for industrialization and development, thereby; studies are sparse on the impacts of land use on soil properties. Therefore, the present study was conducted to investigate and quantitatively delineate the spatial distribution of soil bulk density, organic carbon and $\mathrm{pH}$ under different land use systems.

\section{Materials and Methods}

Study area

The study was conducted in Umuahia South Local Government of Abia State, Southeastern Nigeria. The location of the study area (Fig. 1) is within latitude $5^{\circ} 25^{\prime} 0^{\prime \prime}$ $5^{\circ} 30^{\prime} 0^{\prime \prime} \mathrm{N}$ and longitude $7^{\circ} 22^{\prime} 30^{\prime \prime}-7^{\circ} 32^{\prime} 30^{\prime \prime} \mathrm{E}$ (Chigbu, 2015). The study area is highly populated having an average population density of 2600 inhabitants per square kilometre (Ukandu et al., 2011) and a total area of $140 \mathrm{~km}^{2}$ (Chigbu, 2015). The location of study has a mean annual bimodal rainfall of $2201.92 \mathrm{~mm}$ (Nigeria Meteorological Agency, 2015). The rainfall starts in April and ends in October with peaks in June and September (Nigeria Meteorological Agency, 2015).

Within the location, refuse dump (RD), 4-year bush fallow land (4-BF), forestland (FL), continuously cultivated land (CC), and excavation sites (EX) were investigated. Those sites are located within Ubakala and Ohiya metropolis. The forest had existed for over 50 years with tress such as Swietenia mahogani (mahogany), Milica excelsa (iroko) and Gmelina arborea (gmelina), while the bush fallow land which had been under fallow for four years had trees such as Dialium guineense (mbacheleku), Chromolaena odorata (siam weed), Anthonotha macrophylla (ububa-iepa) and Parinari congensis (ahaba). The refuse dump site had been utilized for more than 12 years for dumping household municipal wastes while the excavation site has been used for over 7 years for mining of laterites for construction of road and housing. The continuously cultivated land has been used continuously for cultivation of crops such as melon, cassava, fluted pumpkin, and maize.

\section{Soilsampling}

Under each land use system, ten (10) sampling points were located randomly. Around each of the sampling points within each land use, soil samples were collected at the depths 0 - 20, 20 - 40 and $40-80 \mathrm{~cm}$ using soil auger and core sampler. This constituted a total of 30 samples for each land use and a grand total of 150 bulk and core samples for the 5 land uses.

\section{Sample preparation}

The auger soil samples were air-dried and sieved through $2 \mathrm{~mm}$ sieve size. The Samples for organic matter were crushed again after sieving with $2 \mathrm{~mm}$ sieve size. The base of the core samples were covered with a cheesecloth and saturated in water for determination of bulk density.

\section{Laboratory analysis}

Bulk density: This was determined by the method reported by Blake and Hartge (1986).

Organic carbon: The organic carbon content of the soil samples was determined as described by Walkely and Black method (Nelson and Summers, 1982).

Soil pH: Soil pH was determined using 1: 2.5 soil-water suspension ratio (McLean, 1982).

\section{Statistical analysis}

With the help of GIS, the soil variables (bulk density, organic carbon and $\mathrm{pH}$ ) were exposed to exploratory analysis. It involved plotting coordinates in a global positioning system (GPS) data file using ArcGIS software. The GPS coordinates were plotted on a map with a base map. The GIS has the flexibility to pick out applicable transformation methodology for each data set.

\section{Results and Discussion}

\section{Bulk density}

Fig. 2 shows the spatial distribution of bulk densities across the different land use systems. The Figure showed that excavation site had a high bulk density with a mean value of $1.70 \mathrm{Mg} \mathrm{m}^{-3}$, while refuse dump site $\left(1.25 \mathrm{Mg} \mathrm{m}^{-3}\right)$, continuously cultivated land $\left(1.47 \mathrm{Mg} \mathrm{m}^{-3}\right)$, 4-year bush fallow $\left(1.37 \mathrm{Mg} \mathrm{m}^{-3}\right)$ and forestland $\left(1.33 \mathrm{Mg} \mathrm{m}^{-3}\right)$ had moderate bulk densities. Table 1 showed that the bulk density increased as the depth increased. The variation in bulk density may be due to the level of organic matter in the soil (Oguike et al., 2018). The high bulk density observed under excavation site may be attributed to the loss of vegetative cover from the soil and the large-scale use of machineries on the sites, which led to the loss of organic matter thereby resulting to the high bulk density. This high bulk density was similar to the findings of Musah (2013). The moderate bulk density observed under refuse dump site may be attributed to the high organic matter content of the site. This finding concurred with that reported by Okolo et al. (2013) who observed that the high level of organic matter in the refuse dump sites of Abakaliki led to high total volume, moderate bulk density and favoured transmission of water under saturated conditions. The variation in bulk density observed under continuously cultivated land may be because of the mechanical disturbance of pore arrangements by tillage (Celik, 2005). The moderate bulk densities of 4-bush fallow and forestland may be because of their high organic matter contents (Oguike et al., 2006; Oguike and Mbagwu, 2009). Oguike et al. (2018) observed that soil organic matter reduced bulk density through the adhesive and bonding properties of organic matter such as bacterial waste. 


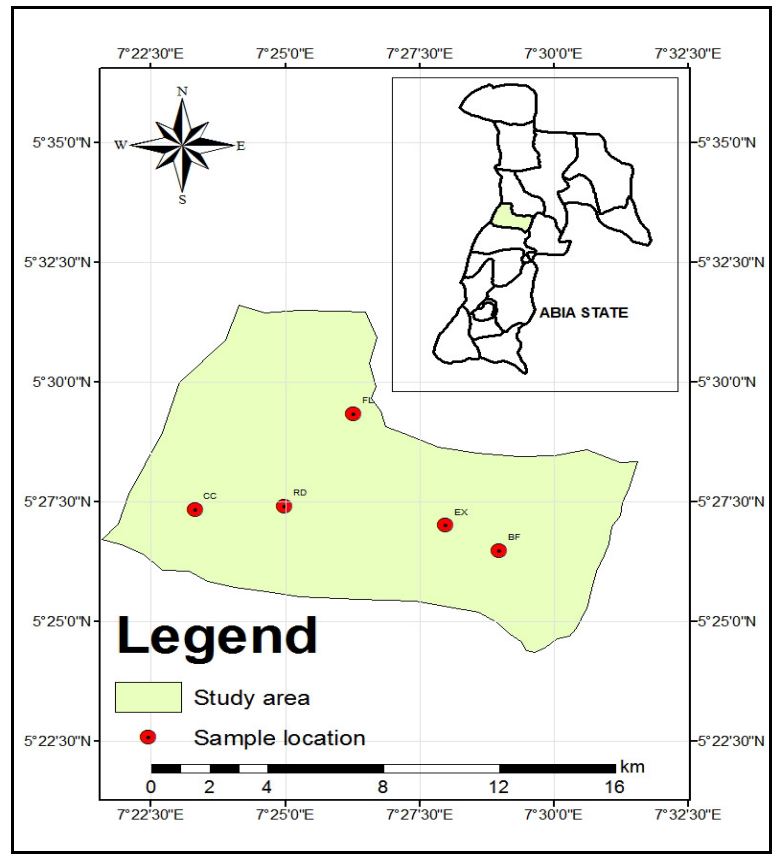

Fig. 1. Map of the study area showing the sample location

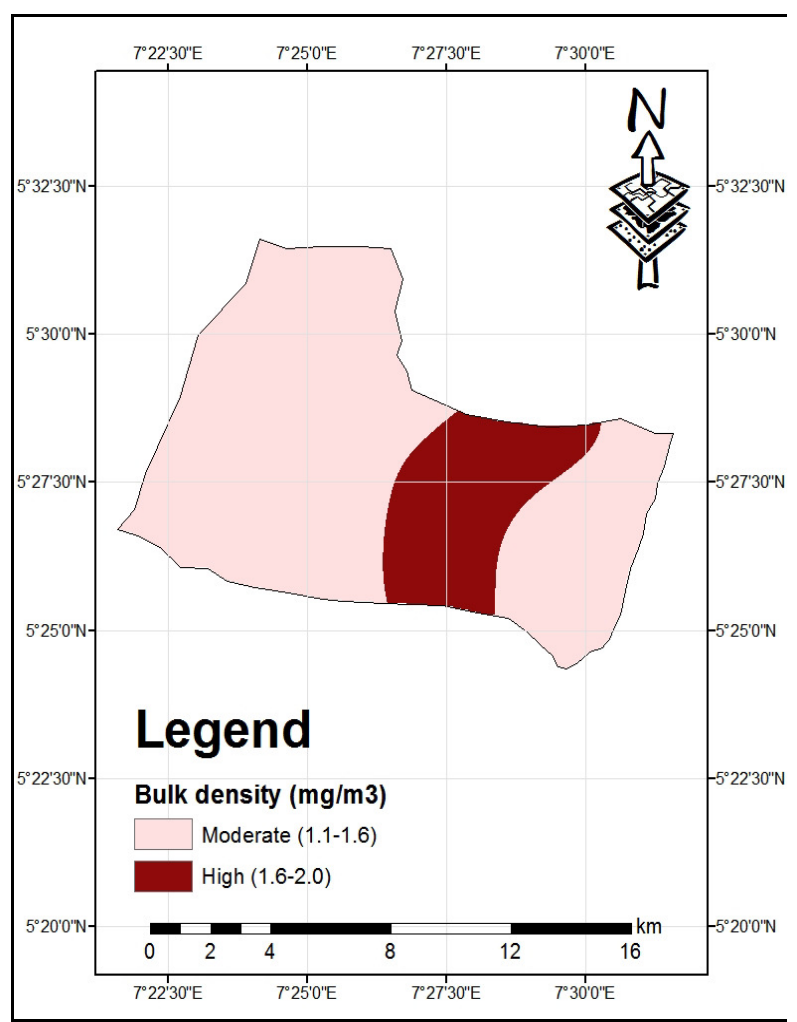

Fig. 2. Soil map showing the spatial distribution of bulk density among the land use systems studied

\section{SoilpH}

The spatial distribution of soil reaction across the different land use systems is shown in Fig. 3. The figure showed that refuse dump site had a neutral soil reaction with a mean value of 7.02, whereas 4-year bush fallow (6.00) and forestland (5.71) were slightly acidic. However, continuously cultivated land with a mean value of 5.41 was moderately acidic while excavation site (4.59) was very strongly acidic in reaction. The soil $\mathrm{pH}$ decreased with increase in depth (Table 1). The neutral and slightly acidic nature of the soils under refuse dump sites, 4-year bush fallow and forestland might be due to release of high exchangeable bases from municipal wastes, litter fall and roots (Alemayeha and Sheleme, 2013). The moderate acidic nature of the soil under continuously cultivated land and very strong acidic nature of excavation sites could be the increase in clay contents resulting from the removal of vegetation and top soil from the area. This increased the tendency of the clay contents to supply hydrogen ions from clay colloidal surface to the solution thereby reducing soil $\mathrm{pH}$ (Oguike and Onwuka, 2017).

\section{Organic carbon}

Spatial distribution of organic carbon among the land use systems studied was quantitatively delineated in Fig. 4. From the figure, it was observed that soil under excavation site had very low organic carbon content with a mean value of $0.38 \%$, while continuously cultivated land (1.48\%) was observed to have a moderate organic carbon content. However, forestland (2.97\%) and refuse dump site (3.20\%) had very high organic carbon contents, while 4-year bush fallow land $(1.91 \%)$ recorded high organic carbon content. The organic carbon content of the soil decreased as the depth increased (Table 1). 
Table 1. Bulk density, organic carbon and $\mathrm{pH}$ of soils studied

\begin{tabular}{|c|c|c|c|}
\hline \multirow{2}{*}{ Land use } & \multicolumn{3}{|c|}{ Soil properties } \\
\hline & $\mathrm{Bd}\left(\mathrm{Mg} \mathrm{m}^{-3}\right)$ & OC (\%) & $\mathrm{pH}$ \\
\hline \multicolumn{4}{|c|}{$0-20 \mathrm{~cm}$} \\
\hline EX & 1.61 & 0.38 & 4.90 \\
\hline $\mathrm{RD}$ & 1.15 & 3.20 & 7.06 \\
\hline $\mathrm{CC}$ & 1.38 & 1.48 & 5.70 \\
\hline $4-B F$ & 1.27 & 1.91 & 6.21 \\
\hline FL & 1.20 & 2.97 & 5.93 \\
\hline \multicolumn{4}{|c|}{$20-40 \mathrm{~cm}$} \\
\hline EX & 1.69 & 0.21 & 4.57 \\
\hline $\mathrm{RD}$ & 1.24 & 2.92 & 6.58 \\
\hline $\mathrm{CC}$ & 1.45 & 1.30 & 5.51 \\
\hline $4-B F$ & 1.36 & 1.62 & 6.02 \\
\hline FL & 1.29 & 2.08 & 5.71 \\
\hline \multicolumn{4}{|c|}{$40-80 \mathrm{~cm}$} \\
\hline EX & 1.81 & 0.18 & 4.30 \\
\hline $\mathrm{RD}$ & 1.36 & 2.10 & 6.16 \\
\hline CC & 1.57 & 0.98 & 5.02 \\
\hline 4-BF & 1.48 & 1.03 & 5.76 \\
\hline FL & 1.51 & 1.68 & 5.48 \\
\hline Mean & 1.42 & 1.60 & 5.66 \\
\hline
\end{tabular}

$\mathrm{EX}=$ excavation site, $\mathrm{RD}=$ refuse dump site, $\mathrm{CC}=$ continuously cultivated land, $4-\mathrm{BF}=4$-year bush fallow land, $\mathrm{FL}=$ forest land.

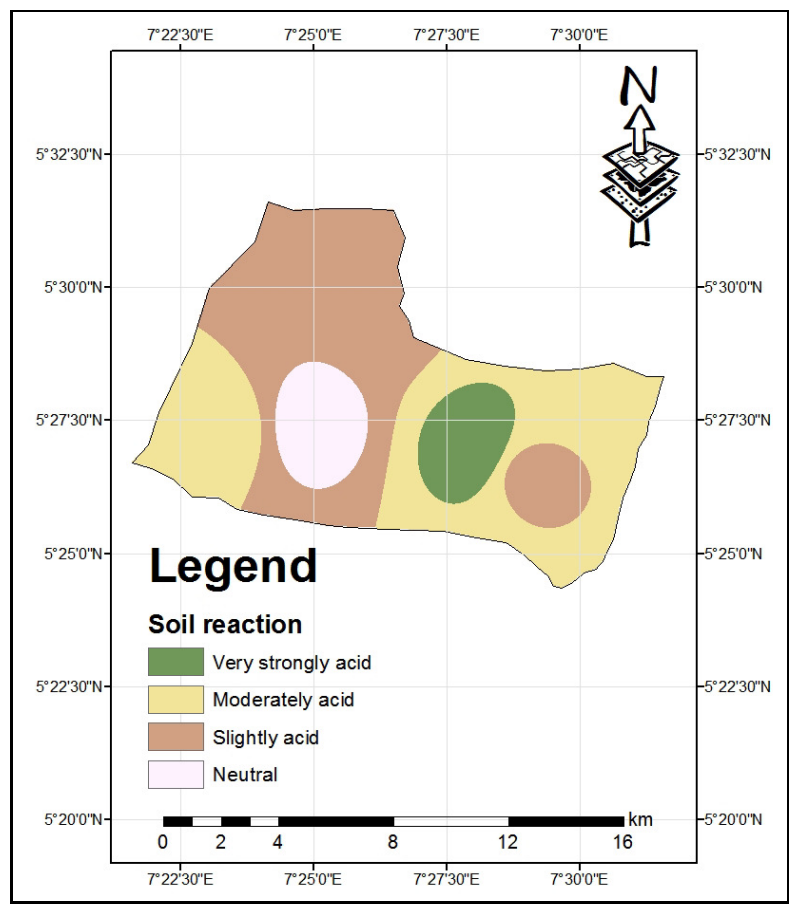

Fig. 3. Soil map showing the spatial distribution of soil $\mathrm{pH}$ among the land use systems studied

The very low organic carbon observed in excavation sites could be attributed to the soil disturbance which may had altered soil profile by destroying vegetation, roots, soil microbes and soil horizon (Musah, 2013). Those excavation activities increased the vulnerability of the soil surface to wind and water erosion. Similar observation had reported that the very low organic carbon might be due to the removal of litter and top soil (Rab, 2003). The very high

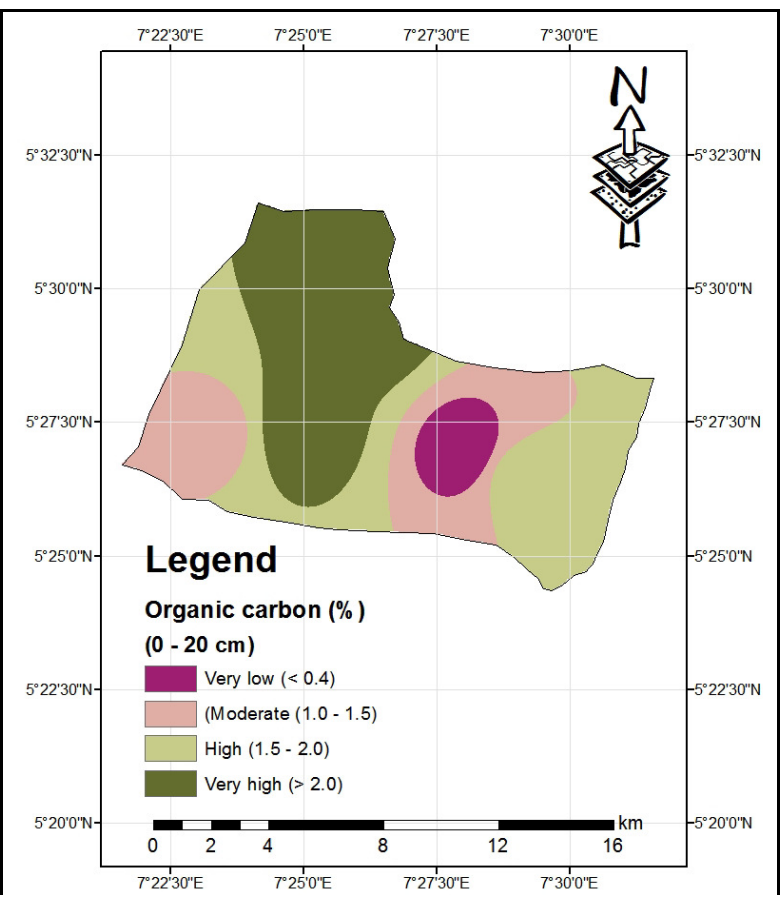

Fig. 4. Soil map showing the spatial distribution of soil organic carbon among the land use systems studied

organic carbon observed under refuse dump sites may be attributed to the use of the sites for dumping wastes (Anikwe and Nwobodo, 2002). Amos-Tauta et al. (2014) in their work on the assessing some heavy metals and physicochemical properties in surface soil under municipal open waste dump sites in Yenegoa, made similar observations with the study on very high organic carbon content of refuse dumpsites. They reported that the high organic carbon could have been due to the presence of degradable and compostable refuse wastes. The moderate organic carbon observed in continuously cultivated land could have been due to the effects of continuous cultivation that aggravates organic carbon oxidation (Wakene, 2001; Malo et al., 2005; Alemayeha and Sheleme, 2013). The high organic carbon under 4-year bush fallow and very high organic carbon in forestland may be attributed to the continuous input and decomposition of litter falls and roots (Kleber et al., 2011; Wu et al., 2011). This was in agreement with the findings of Urisotle $e t a l$. (2006) on possibility of high organic carbon content in soil due to presence of roots of grasses and trees and the hyphae of fungi under bush, fallow and forestland.

\section{Conclusions}

The selected soil properties were spatially distributed among the different land use systems. Bulk density varied across the different land use systems under the impact of organic carbon. Higher soil bulk density was observed under excavation site than other land use systems studied. The hydrogen ion concentration of the soils studied was within moderately acidic to very strongly acidic. Organic carbon was generally very low in excavation site and moderate in continuously cultivated land, but very high in refuse dump 
302

site and forestland. The delineated spatial distribution of the selected soil properties in the area will guide land users in soil management strategies, in terms of choice and adoption of land for different uses in the area.

\section{Conflict of Interest}

We declare that there is no conflict of interest between authors.

\section{References}

Agoume V, Birang AM (2009). Impact of different land use systems on some physical and chemical properties of an oxisol in the humid forest zone of southern Cameroun. Tropicultura 22(1):15-20.

Alemayeha K, Sheleme B (2013). Effects of land use systems on selected soil properties in South Ethiopia. Journal of Soil Science and Environmental Management 4(5):100-107.

Amos-Tauta BMW, Onigbinde AO, Diepreye ERE (2014). Assessment of some heavy metals and physio - chemical properties in surface soils of municipal open waste dump site in Yenegoa, Nigeria. African Journal of Environmental Science and Technology 8(1):41-47.

Anikwe MA, Nwobodo KC (2002). Long term effects of household municipal waste dispersal on soil properties and productivity of sites used for urban agricultural in Abakaliki. Nigeria Bioresource Technology 83(3):241-250.

Barlow J (2007). Quantifying the biodiversity value of tropical primary secondary and plantation forest. Proceedings of the National Academy ofSciences 104(47):18555-18560.

Blake GR, Hartge KH (1986). Bulk density. In: Klute, A., Ed, Methods of Soil Analysis, Part 1-Physical and Mineralogical Methods, 2nd Edition, Agronomy Monograph 9, American Society of Agronomy-Soil Science Society of America, Madison, pp 363-382.

Bouma J (1997). The role of quantitative approaches in soil science when interactingwith stakeholder. Geoderma 78(1):1-12.

Braimoh AR, Velk PL (2004). The impacts of various land cover change in soil property in Northern Ghana. Land Degradation and Development 15(1):65-74.

Cambardella CA, Moorman TB, NovakJM,Parkin TB, Karlen DL, Turco RF, Konopka AE (1994). Field-scale variability of soil properties in central Iowa soils. Soil Science Society of America Journal 58(5):15011511.

Celik I (2005). Land use effect on physical properties and organic matter of soil in a southern Mediterranean highland of Turkey. Soil and Tillage Research 83(2):270-277.

Chigbu N (2015). Land use and land cover changes studies and environmental sustainability through spatial intelligence. Department of Surveying and Geo informatics, Abia State polytechnic, Aba.

Chukwu GO, Ezenwa MIS, Osunde AO, Asiedu R (2007). Spatial distribution of nitrogen, phosphorus and potassium in major yam soils of southeastern Nigeria. African Journal of Biotechnology 6(24):28032806.

Croke J, Hairsine P, Figarty P (2001). Soil recovery from track construction and harvesting charges in surface infiltration, erosion and delivery rates with time. Ecological Management 143(1-3):3-12.
Eppink FV, Vander Bengh JC, Rieveval P (2004). Modelling of biodiversity, land use and urban growth. Agriculture and nature in wetland area. Ecological Economics 51(3-4):201-206.

Kleber M, Nico PS, Plante AF, Filley T, Kramer M, Swanston C, Collins P (2011). Old and stable soil organic matter is not necessarily chemically recalcitrant. Implications for modelling concepts and temperature sensitivity. Global change. Biology 17(2):1097-1107.

Malo DD, Schumacher TE, Doolittle JJ (2005). Long-term cultivation impacts on selected soil properties in the Northern Great Plains. Soil Tillage Research 81(2):277-291.

Mao R, Zing DA, Hu YL, Li LJ, Yang D (2010). Changes in soil particulate organic matter microbial biomass and activity following afforestation of marginal agricultural lands in a semi-arid area of North east China. Environment Management 46(1):110-116.

Mclean EO (1982). Soil $\mathrm{pH}$ and lime requirement. Methods of soil analysis. Part 2. Chemical and microbiological properties (methodsofsoilan2), pp 199-224.

MostafaES, Nazor AK (2012). The effect of deep excavation induced lateral soil movement on the behaviour of strip footing supported on a reinforced sand. Journal of Advanced Research 3(4):337-344.

Musah AJ (2013). Assessing the socio-economic and ecological implications of gravel mining in the Savelogu-Nanton District of the northern region of Ghana. Thesis Submitted to the Department of Agroforestry, Faculty of Renewable Natural Resources, Kwame Nkrumah University of Science and Technology.

Nelson DW, Summers LE (1982). Total organic matter in methods of soil analysis part II. Page A.L. (eds) Chemical and microbiological properties. American Society of Agronomy, Maidson WI. Pp 359-580.

Neris J, Jimenez C, Fuentes J, Morillas G, Tejedor M(2012). Vegetation and land use system effect in soil properties and water infiltration of Andisols in Tenerife(Canary Island, Spain). Catena 98:55-62.

Nigeria Meteorological Agency (2015). Seasonal rainfall prediction for 2015 Nigeria meteorological publications. Maitana, FCT Abuja.

Oguike PC, Chukwu GO, Njoku NC (2006). Physio-chemical properties of a haplic acrisol in South Eastern Nigeria amended with rice waste and NPK fertilizer. African Journal of Biotechnology 5(11): 1058-1061.

Oguike PC, Mbagwu JSC (2009). Variations in some physical properties and organic matter content of soils of coastal plain sand under different land use types. World Journal of Agricultural Science 5(1): 63-69.

Oguike PC, Onwuka BM (2017). Variations in texture, water retention and transmission, organic matter and ph of soils under selected land use systems at Ubakala Umuahia, South-Eastern Nigeria. Journal of Scientific and Engineering Research 4(7):147-155.

Oguike PC, Onwuka BM (2018). Moisture characteristics of soils of different land use systems in Ubakala Umuahia, Abia State, Nigeria International Journal of Scientific and Research Publications, 8(4):1723.

Oguike PC, Onwuka BM, Agugo BAC, Onwumere LO (2018). Bulk density and organic matter content of soils of contrasting textural classes in Umuahia area of Abia State, Southeastern Nigeria. International Journal of Agriculture and Rural Development 21(1):3492-3497.

Okolo CC, Nwite JN, Ezeaku PE, Eke NC, Ezeudo VC, Akamigbo FOR (2013). Assessment of selected physiochemical properties of soils for site 
suitable for waste disposal in Abakaliki, South East, Nigeria. Journal of Resources Development and Management 1:26-29.

Paz-Gonzâlez A, Vieria SR, Taboada Castro MT (2000). The effect of cultivation on the spatial variability of selected properties of an umbric horizon. Geoderma 97(3-4):273-292.

Rab MA (2003). Recovery of soil physical properties from compaction and soil disturbance caused by logging of native forest in Victorian central Highlands, Australia. Forest Ecology and Management 191(1-3):329340.

Rab MA, Anderson H, Boddington D, Van Reess H (1992). Soil disturbance and compaction in: Squire, RO. (ed). First interim report for the value adding utilization system trial. Department of conservation and environment, Victoria, Australia. Pp 25-31.

Shepherd G, Bareh RJ, Gregory PJ (2000). Land use affects the distribution of soil inorganic nitrogen in small holder production systems in Kenya. Biology andFertility ofSoils 31(3-4):348-355.

Singh S, Singh JS (1996). Water stable aggregates and associated organic matter in forest, savannah and crop land soil of a seasonally dry tropical region, India. Biology and Fertility ofSoil 22(1-2):76-82.

Six J, Paustian K, Elliot ET, Combrink C (2000). Soil structure and organic matter. In distribution of aggregate size classes and aggregate associated carbon. Soil Science Society of America Journal 64(2):681-689.

Skye AW (2005). The spatial distribution of soil properties and prediction of soil organic carbon in Hayden Prairie and an adjacent agricultural field. A dissertation submitted to the Graduate Faculty in partial fulfilment of the requirements for the degree of Doctor of Philosophy, Iowa State University, Ames, Iowa, pp75.
Soil Survey Staff(1996). Soil survey laboratory methods manual. Soil Survey Investigations Report No. 42, version 3.0. U. S. Government Printing Office, Washington DC.

Ukandu JS, Udom GJ, Nwankwoala HO (2011). Aspect of the hydrogeology of Umuahia

South Local Government Area, Abia State, Nigeria. Journal of Environmental Research and Management 2(2):14-26.

Urisotle AM, Hevia GG, Hepper EN, Antion LE, Borio AA, Buschiazozo DE (2006). Cultivation effects in the distribution of organic carbon, total nitrogen and phosphorus in soils of the semi-arid region of Argentinian Pampas. Geoderma 136(3-4): 621-630.

Versterdal L, Ritter E, Gundersen P (2002). Change in soil organic carbon following afforestation of former arable land. Forest Ecology and Management 169(1-2):137-147.

Webster R, Oliver MA (2001). Geostatistics for environmental scientists. John Wiley \& Sons Inc. Chichester,England. pp 23.

Wakene N (2001). Assessment of important physiochemical properties of Dystric Udalf (Dystric Nitosols) under different management systems in Bako area. Western Ethiopia. M.Sc. thesis submitted to School of GraduateStudies, Alemaya University, Ethiopia. Pp 93.

Wu W, YangP, Tang H, Dagaro L, Shibasaki R (2011). Regional variability of the effects of land use systems on soil properties. Agricultural Sciences in China 6(11):1369-1375. 